\title{
A KÉPESSÉGALAPÚ ÉRZELMI INTELLIGENCIA: ÚJ PARADIGMÁK A TESZTFEJLESZTÉSBEN ÉS PONTOZÁSBAN. HAZAI TAPASZTALATOK AZ ÉRZELEMMEGÉRTÉS ÉS ÉRZELEMSZABÁLYOZÁS SZITUÁCIÓS TESZTEKKEL
}

\author{
NAGY HENRIETT¹ - MAGYARÓDI TÍMEA ${ }^{1}$ - SÉLLEI BEATRIX² \\ ${ }^{1}$ Eötvös Loránd Tudományegyetem Pszichológiai Intézet \\ ${ }^{2}$ Budapesti Műszaki és Gazdaságtudományi Egyetem, \\ Gazdaság- és Társadalomtudományi Kar, Ergonómia és Pszichológia Tanszék \\ e-mail:nagy.henriett@ppk.elte.hu
}

Beérkezett: 2014. augusztus 25. - Elfogadva: 2015. augusztus 24.

\begin{abstract}
Jelen tanulmány két, a MSCEIT (Mayer-Salovey-Caruso Érzelmi Intelligencia Teszt) alternatívájaként megjelenö érzelmi intelligencia (EI) tesztre: az Érzelemmegértés (STEU) és az Érzelemszabályozás (STEM) szituációs tesztekre fókuszál. A STEU azért újszerü megközelités az EI-mérés területén, mert bevezeti a sztenderdekre épülö pontozás lehetöségét, a STEM pedig azért, mert az SJT (situational judgement test method) megközelitést alkalmazza. Jelen kutatás célja a STEU-és STEM-tesztek magyar változatainak elkészitése, valamint a tesztek megbízhatóságával és validitásával kapcsolatos bizonyitékok bövitése. A tesztek érvényességének vizsgálata során a STEU-és STEM-pontszámok fluid intelligenciával, vonás EI-vel, érzelemfelismerő képességgel, személyiséggel, valamint az alexithymiával és az élettel való elégedettséggel mutatott együttjárásait elemeztük. Konklúzióként megállapithatjuk, hogy ezek az új tesztfejlesztési, illetve pontozási megközelitések hasznosak és igéretesek a képességalapú EI-mérés területén, ugyanakkor további vizsgálatok szükségesek, ha igazolni szeretnénk, hogy a STEUés a STEM-tesztek inkább mérnek érzelmi intelligenciát, mint más kognitív képességet, illetve, hogy az EI-feladatok együttesen különálló faktort alkotnak, amely megkülönböztethetö más kognitív képességektôl.

Kulcsszavak: képességalapú érzelmi intelligencia, Érzelemmegértés Szituációs Teszt, Érzelemszabályozás Szituációs Teszt
\end{abstract}




\section{BEVEZETÉS}

A képességalapú érzelmi intelligencia modell leírói (SALOveY és MAYER, 1990; MAYER és SALOVEY, 1997) érzelmekkel összefüggő mentális képességek (az érzelmek észlelése és kifejezése, felhasználása, megértése és szabályozása) halmazaként definiálják az érzelmi intelligenciát (EI), és azt állítják, hogy az EI-fogalom alá sorolt képességek egy, az IQ-tól világosan megkülönböztethető, önálló intelligenciaformát alkotnak. A képességalapú EI-modellel kapcsolatban felmerülő legjelentősebb problémák a következők: 1. lehet-e mérni a modellbe sorolt érzelmi képességeket teljesítménytesztek alkalmazásával, vagyis összeállíthatóak-e olyan feladatok, amelyeket az EI-modellbe foglalt érzelmi képességek felhasználásával kell megoldani és amelyekben egyértelmüen kijelölhetők a helyes válaszok, 2. a modellbe sorolt érzelmi képességek önálló intelligenciaformát alkotnak-e, vagyis érvényesek-e rájuk nézve az intelligencia standard kritériumai (fogalmi, korrelációs, fejlődési; lásd MaYer, CARuso és SALOvey, 1999). Jelen tanulmány mindkét problémakörhöz kapcsolódik. Vizsgálatunkban az Érzelemmegértés (Situational Test of Emotional Understanding, STEU; MACCANn és RoberTs, 2008) és az Érzelemszabályozás (Situational Test of Emotion Management, STEM; MACCANN és ROBERTS, 2008) szituációs tesztek hazai adaptációjára vállalkozunk. Ezek a tesztek felnőtt korúak érzelmi intelligenciájának mérésére alkalmasak teljesítményhelyzetben, és újszerủ megoldásokat alkalmaznak a tesztszerkesztésben, illetve az EI-feladatok ún. „helyes válaszainak” meghatározása során.

\section{A HELYES VÁLASZMEGHATÁROZÁS PROBLEMATIKÁJA}

Az EI-t mérő teljesítménytesztekkel szemben megfogalmazott legfőbb kritika az ún. „helyes válasz” problematika, amely azt a nézőpontot fogalmazza meg, hogy az érzelmi problémákat bemutató feladatokat nem lehet megfelelő objektivitással értékelni/pontozni, mert nincs világos kritérium arra vonatkozólag, hogy mi a jó vagy a jobb megoldás (ROBERST, ZEIDNER és MATTHEWS, 2001; ZEIDNER, MATTHEws és ROBERTS, 2001). Felmerül, hogy az érzelmekkel kapcsolatos problémahelyzetekben, bármely válasz elfogadható lehetséges értelmes viszonyulásként. Kiindulhatunk ugyanis abból, hogy az érzelem elválaszthatatlan része a szituáció kognitív kiértékelése, és a tesztkitöltő saját tapasztalatai, stílusa, automatizmusai befolyásolhatják azt, hogyan válaszol egy bemutatott érzelmi problémahelyzetre. E gondolatmenet szerint az, hogy a vizsgált személy a különböző teszttételek esetén milyen válaszalternatívát választ, legalább annyit elárul a személyiségéről, mint az érzelmi intelligenciájáról. Ebben az értelemben az érzelmi problémák prezentálása és az erre adott válaszreakció értékelése sokkal inkább projektív technikaként értelmezhető, mint teljesítménytesztként. A teljesítménytesztekkel történő EI-mérés kapcsán tehát a megoldandó probléma olyan az érzelmi képes- 
ségek mérésére alkalmas feladatsor összeállítása, amelyben a pontozást objektív módon tudjuk meghatározni, és ahol a személy teljesítménye független személyiségének jellemzőitől.

Az EI-tesztfejlesztés területén a tételek objektív pontozására a szakértői és a konszenzuskritériumok alkalmazása terjedt el (SALOVEY és MAYER, 1990). A szakértői kritérium esetében az EI-tesztek tételeire a helyes válaszokat klinikai pszichológusok és/vagy érzelemkutatók válaszai alapján határozzák meg. Leggyakrabban arra kérik a szakértői mintát, hogy a bemutatott érzelmi probléma kapcsán megfogalmazott válaszalternatívák hatékonyságát Likert-típusú skálákon értékeljék, majd később a teszt pontozásakor a szakértők értékeléseinek átlagértékét veszik figyelembe.

Az empirikus adatokra épülő konszenzuskritérium esetén nagy minták eloszlási jellemzői alapján határozzák meg a pontozást. Például ha egy bemutatott érzelmi problémánál a felkínált első válaszlehetőséget a minta 10\%-a gondolja jó megoldásnak, akkor ez a válasz a pontozáskor 0,1 pontot ér majd, és így tovább. Ez a pontozás lényegében összegyüjti az általánosan, egy kultúrán belül elfogadott érzelmi reakciókról szóló tudást. MAYER, SALOVEY, CARUSO és SITARENIOS (2001), akik az EI mérése területén a konszenzusos pontozás alkalmazhatósága mellett érvelnek, azt hangsúlyozzák, hogy mivel az érzelmi információk „életbevágóan fontos témákban” relevánsak, valószínűsíthető, hogy létezik egy-egy általános konszenzus számos érzelem jelentése kapcsán. A konszenzuson alapuló pontozás nem jelenti azt, hogy az érzelmek értelmezésének csak egy útja lehetséges, csupán arra utal, hogy rendelkezünk egy kulturálisan összegyűlt tudással az érzelmek általános jelentésével kapcsolatban, ami alapján össze tudjuk hasonlítani egy személy reakcióját azzal, ahogy az emberek egy bizonyos helyzetre tipikusan reagálnak, és meg tudjuk ítélni, hogy melyik érzelmi reakció az, ami általában adaptívabb és jobb alkalmazkodáshoz vezet.

LEGREE (1995) szerint a szakértői értékelés valójában nem különbözik a csoportkonszenzus előrejelzésénél, hiszen a szakértők a közösség azon tagjai, akik nagyon sokat tudnak a csoportkonszenzusról (vagyis arról, hogy általában hogyan vélekednek az emberek). Ezt a nézetet empirikus bizonyítékok is támogatják, a Mayer-Salovey-Caruso Érzelmi Intelligencia Teszt (MSCEIT) kétfajta pontozása (szakértői és konszenzusos) magas szinten együtt jár ( $r=0,93-0,98)$ (MAYER, SALOVEY és CaRuso, 2002).

Néhányan megkérdőjelezik a fenti pontozási eljárások érvényességét, és a konszenzusra építő kritérium ellenében felhozzák, hogy az lényegében lehetetlenné teszi a nagyon nehéz tételek beépítését az érzelmi intelligenciát mérő tesztekbe, így a tesztek nem alkalmasak az igazán magas szintű érzelmi intelligenciával rendelkező személyek azonosítására (ROBERTS, ZEIDNER és MATTHEWS, 2001; MATTHEws, ZEIDNER és ROBERTS, 2007). ROBERST és munkatársai (2001) továbbá felvetik, hogy a konszenzusos pontozás alkalmazása mellett az EI lényegében a többségi normának való megfelelésen keresztül nyújt szociális előnyöket, ez pedig szemben áll azzal a szándékolt elméleti kerettel, mely szerint az EI kapcsán az adaptivitás a kognitív képességek kifinomultságából fakad. 


\section{AZ MSCEIT ÉS ALTERNATÍVÁI: ÉRZELEMMEGÉRTÉS ÉS ÉRZELEMSZABÁLYOZÁS SZITUÁCIÓS TESZTEK}

Az EI legismertebb teljesítménytesztjei: a Multifaktoriális Érzelmi Intelligencia Skála (Multifactorial Emotional Intelligence Scale, MEIS; MaYer, SALOvey és CARUSO, 1997), valamint ennek továbbfejlesztett változata az MSCEIT (MAYER és mtsai, 2002). Az MSCEIT 141 tételből áll, négy alskálája a MAYER és SALOVEY-féle (1997) EI modell 4 ágának feleltethető meg. Az érzelmek észlelését arcok, festmények, absztrakt rajzok által közvetített érzelmek felismerésén keresztül, az érzelmek felhasználását különböző érzelmek más érzékletekkel (színekkel, ízekkel) való párba állítása, az érzelmek megértését a különböző érzelmek közötti kapcsolatok felismerése, az érzelmek szabályozását pedig különböző érzelmeket implikáló történetekre adott reakciók szociális következményeinek megitélése révén méri a teszt. A hierarchikusan szerveződő modellben a magasabb szintű ágak függnek az alacsonyabb szintűektől, illetve az alsóbb két ág (érzelmek észlelése és felhasználása) együtt a tapasztalati EI, a magasabb szintủ két ág (érzelmek megértése és szabályozása) pedig a stratégiai EI konstruktumait különbözteti meg (MAYER és mtsai, 2001). Bár az MSCEIT megbízhatóságát és validitását számos tanulmány vizsgálta - és ezek többsége támogatta a teszt érvényességét (lásd MAYER, ROBERTS és BARSADE, 2008) - a mérőeszközzel kapcsolatban lényeges kritikai észrevételek fogalmazhatóak meg (Keele és Bell, 2008; Palmer, Gignac, Manoca és Stough, 2005; Rossen, KRANZLER és ALGINA, 2008). A mérőeszköz 8 altesztje közül 6 többfokozatú skálát alkalmaz a válaszok megjelölésekor (nem egy jó választ kell megjelölni, hanem az egyes válaszalternatívák helyénvalóságát kell megítélni többfokozatú skálák alkalmazásával), ami nem megszokott a kognitív teljesítményteszteknél. További kritika, hogy a teszt az EI-nek egy általános értelmezését adja, miközben nagyon speciális feladatokon alapul (mindösszesen kétféle feladat mér egy-egy képességet). Az MSCEIT strukturális validitása szintén megkérdőjelezhető, számos empirikus tanulmány szerint nem mutatható ki megfelelő illeszkedés az elméleti faktorstruktúrával.

Mindezek alapján indokolt alternatív mérési eljárások kidolgozása a képességalapú EI területén. Jelen tanulmány a két legismertebb, az MSCEIT alternatívájaként megjelenő EI-tesztre: az Érzelemmegértés (STEU; MACCANN és ROBERTS, 2008) és az Érzelemszabályozás (STEM; MACCANN és ROBERTS, 2008) szituációs tesztekre fókuszál.

A STEU azért újszerű megközelítés az EI-mérés területén, mert bevezeti a sztenderdekre épülő pontozás lehetőségét (a feladat összeállítása elmélet vezérelten történik, az elmélet jelöli ki a jó megoldást) és lehetővé teszi az intelligenciatesztekhez hasonló módon a tételek dichotóm pontozását. Az érzelemmegértés képességét operacionalizáló STEU az elméletalapú tesztszerkesztés példája az EImérés területén. A tételek összeállítása és a helyes válaszok meghatározása egyaránt Roseman (2001) érzelemelméletére épül (lásd 1. táblázat), amely leírja, hogy hogyan generálódik 17 diszkrét emóció (öröm, remény, megkönnyebbülés, szeretet, büszkeség, szomorúság, distressz, frusztráció, undor, ellenszenv, harag, megvetés, megbánás, bűnösség, szégyen, meglepetés, félelem), hét értékelési dimenzió 


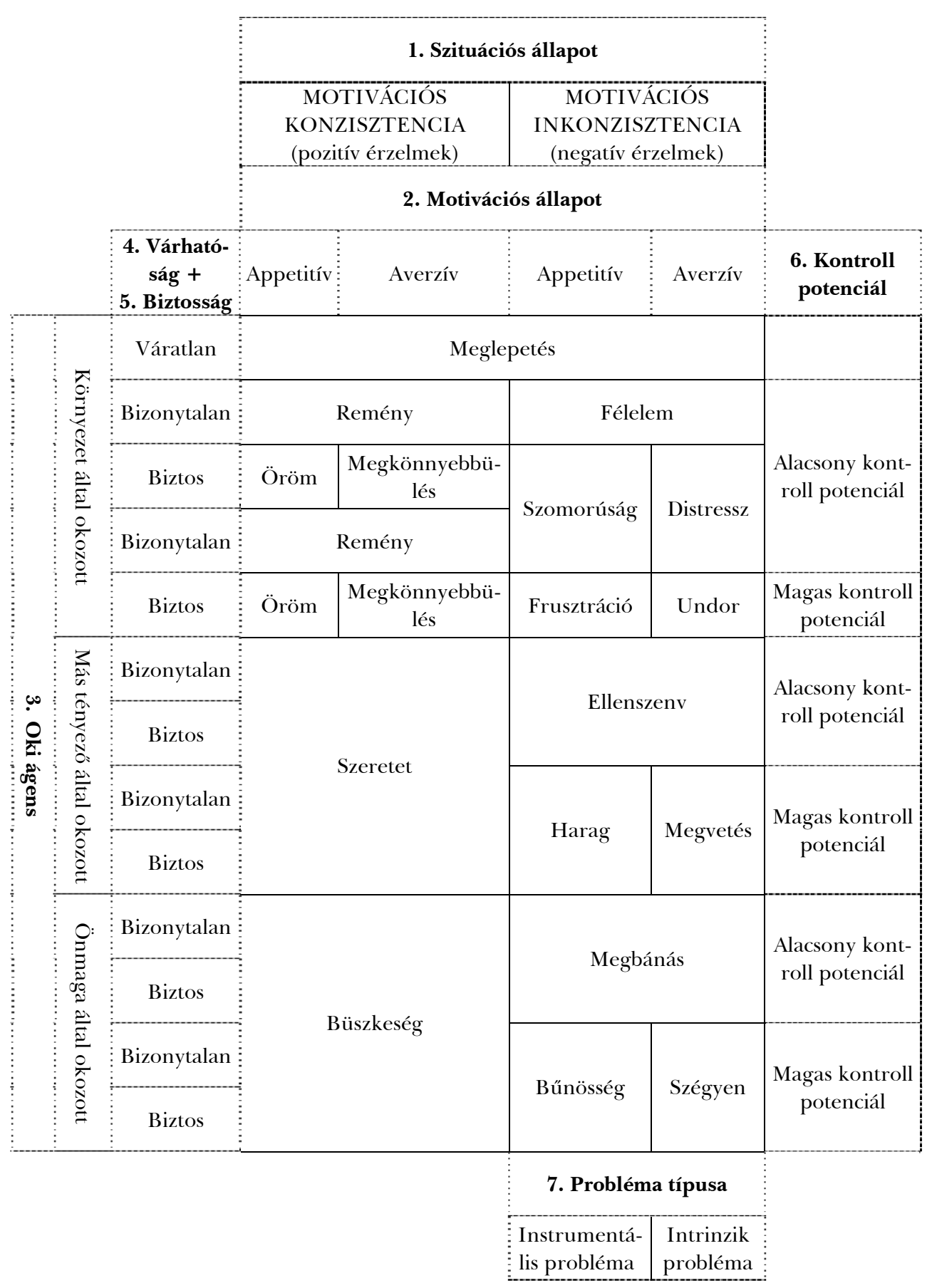

1. táblázat. RoSEMAN (2001) érzelemelmélete 
(szituációs állapot, motivációs állapot, oki ágens, várhatóság, biztonság, kontroll potenciál, probléma típus) specifikus kombinációja alapján. MACCANN és ROBERTS (2008) úgy alakították ki a STEU tételeit, hogy az azokban leírt szituációk 14 érzelemnek feleljenek meg, amelyek az elméletet követve az értékelési dimenziók specifikus kombinációját reprezentálják. Például Roseman érzelemelmélete szerint a megkönnyebbülés ahhoz az értékeléshez kapcsolódik, hogy egy kellemetlenként értékelt szituáció véget ért vagy múlóban van. A teszt szerkesztői ezen állításhoz illeszkedően fogalmazták meg a következő szituációt: „Éva idegesítő szomszédja végre elköltözik”, a megválaszolandó kérdés pedig: „Mi az, amit Éva a legvalószínủbben érez?” Az elméletből kiindulva ennél a tételnél a helyes válasz a megkönynyebbülés, a további válaszalternatívák (sajnálat, remény, szomorúság, öröm) pedig rossz megoldásként értelmezhetők.

Az érzelemszabályozás képességét (a negatív érzelmek mérséklésének és a pozitívak előidézésnek képessége, MAYER és mtsai, 1999) mérő STEM empirikus alapú tesztszerkesztésre épül, a helyes válaszok meghatározása konszenzusra épülő kódolással történik. A STEM azért újszerủ tesztszerkesztési kísérlet az EI-mérés területén, mert az SJT- (situational judgement test method; MCDANIEL, MORGESON, FinNEGAN, CAMPION és BRAVEman, 2001) megközelítést alkalmazza a tesztfejlesztésben, vagyis szituációkat mutat be a tesztkitöltőknek, majd arra kéri a résztvevőket, hogy döntsenek a szituációkról és azonosítsák azokban a leghatékonyabb választ. A teszt instrukciója hangsúlyozza, hogy nem arra vagyunk kíváncsiak, hogy a személy mit tenne az adott szituációban, vagy hogy melyik reakció volna szerinte a legszimpatikusabb válasz, hanem arra kérjük a tesztet kitöltő személyt, hogy azt a választ jelölje meg, amely szerinte a leghatékonyabb reakciót írja le az adott helyzetben, vagyis amely egyszerre kezeli a személy érzelmeit és oldja meg a felmerülő problémát. A STEM kifejlesztése az alábbi lépésekben zajlott: 1 . az érzelmi szituációk összegyűjtése, 2 . válasz opciók generálása, 3. pontozási kulcs kialakítása. Az érzelmi szituációk összegyűjtése 50 fős felnőtt minta alkalmazásával történt, a résztvevők interjúhelyzetben beszéltek azokról az érzelmi szituációkról, melyek az elmúlt két hétben történtek velük. A válasz opciók generálásához egy másik 99 föből álló egyetemista mintát alkalmaztak a teszt szerkesztői. A résztvevőknek az első szakaszban meghatározott érzelmi szituációkban kellett leírni, hogy mi lenne a lehetô legjobb dolog, amit lehetne tenni ebben a szituációban, illetve ők mit tennének, ha ebbe a szituációba kerülnének. A tesztfejlesztés során később MACCANN és ROBERTS (2008) azokat a szituációkat tartották meg, ahol nagy variabilitású válaszok születtek. Végezetül a pontozási kulcs kialakításához egy harmadik, klinikai pszichológusokból és érzelemkutatókból álló mintát használtak fel. A szakértők kétféle módon is értékelték az egyes szituációkhoz tartozó válaszlehetőségeket $a$ ) a négy felkínált válaszalternatíva közül kiválasztották a leghatékonyabbat (ez esetben a pontozás az alapján történik, hogy a szakértők milyen arányban választották megoldásként az adott választ), b) a szakértők egy hatfokozatú skála segítségével értékelték minden egyes válasz hatékonyságát (ez esetben a pontozás a szakértők átlagértéke alapján történik). 


\section{A TANULMÁNY GÉLKITŰZÉSEI}

Az Érzelemmegértés Szituációs Tesztjét (STEU), illetve az Érzelemszabályozás Szituációs Tesztjét (STEM) MACCANN és ROBERTs dolgozták ki 2008-ban. Jelen kutatás célja a STEU- és STEM-tesztek magyar változatainak elkészítése, valamint a tesztek megbízhatóságával és validitásával kapcsolatos bizonyítékok bővítése. A magyar változatok elkészítésében BEATON, BOMBARDIER, GUILLEMIN és FERRAZ (2000) kérdőív-adaptációs módszertani leírását alkalmaztuk. Előzetesen - miután megkaptuk a szerzők engedélyét a tesztek fordításához és adaptálásához - elvégeztük a tételek magyarra fordítását, majd miután egy angol szaktolmács elvégezte a tételek visszafordítását, megtörtént a fordítás korrekciója is.

A tesztek érvényességének vizsgálata során a STEU- és STEM-pontszámok fluid intelligenciával, vonás EI-vel, érzelemfelismerő képességgel, személyiséggel, valamint az alexithymiával és az élettel való elégedettséggel mutatott összefüggéseit elemezzük. A képességalapú érzelmi intelligenciával szemben MAYER és munkatársai (1999) alapján támasztott ún. korrelációs kritérium értelmében az EI-teszten elért pontszámok és az intelligenciateszten elért pontszám között közepes erősségű pozitív kapcsolatot várunk. További elvárás, hogy az EI-teszteken elért pontszám legfeljebb alacsony mértékủ korrelációt mutasson a személyiséggel, illetve az alexithymia és élettel való elégedettség kapcsolatban álljanak az EI-pontszámokkal.

\section{MÓDSZER}

\section{Résztvevők}

A vizsgált személyek az Eötvös Loránd Tudományegyetem, illetve a Budapesti Műszaki Egyetem önként jelentkező hallgatói voltak, akik különböző egyetemi kurzusokon értesültek a kutatásról, itt jelezhették a részvételi szándékukat az e-mail címük megadásával. A vizsgálatban összesen 424 fó vett részt, 176 férfi és 186 nő (62 fö nem nyilatkozott a nemével kapcsolatban). A legfiatalabb résztvevő 18 éves volt, a minta átlagéletkora: 23,83 év $(\mathrm{SD}=6,73)$.

\section{Eljárás}

A kutatás online felületen történt, a vizsgált személyek az online felület kezdő lapján egy írásos tájékoztatót olvastak a kutatásról, majd a részvételi szándékukat a „hozzájárulok” gomb megnyomásával jelezték. Ezt követően jelent meg a beleegyező nyilatkozat szövege, amennyiben a résztvevő egyetértett az ebben foglalt feltételekkel, ezt az „elfogadom” gomb megnyomásával jelezte. A vizsgált személyek az általuk szabadon választott időpontban és helyszínen töltötték ki a kérdőíveket. 


\section{Eszközök}

Az eljárás során a STEU- és STEM-tesztek adminisztrációja mellett egy fluid intelligenciát mérő tesztet, egy vonás EI-t mérő kérdőívet, az érzelmi arcfelismerés képességét mérő Ekman 60 Arcok tesztet, a személyiség ötfaktoros elméletére épülő BFI-kérdőívet, valamint az alexithymia és az élettel való elégedettség mérőeszközeit alkalmaztuk.

A STEU 42 tételből áll, minden tétel egy szituációt ír le, a tesztkitöltő személynek pedig öt érzelemből kell kiválasztani azt, ami a legvalószínúbben jelenik meg az adott helyzetben. A szituációk részben munkahelyi, részben magánéleti helyzeteket írnak le. A 1. ábra példaként bemutat egy itemet a teszt tételei közül.

Julcsi egy szabadtéri pikniket tervez, és a tervezett napon nagyon szép idő van. Mi az, amit Julcsi a legvalószínúbben érez?

$$
\begin{aligned}
& \text { a) büszkeség } \\
& \text { b) öröm } \\
& \text { c) megkönnyebbülés } \\
& \text { d) bűntudat } \\
& \text { e) remény }
\end{aligned}
$$

(A helyes válasz: $b)$.)

1. ábra. Egy példa a STEU itemei közül

A STEM 44 tételből áll, minden tétel egy szituációt ír le, és négy válaszlehetőség közül kell kiválasztani az adott helyzetben leghatékonyabb reakciót. A 2. ábra példaként bemutat egy itemet a teszt tételei közül.

Lajos munkatársa elmulasztott időben átadni egy fontos információt, ennek következtében Lajos is elmaradt a munkájában. Mi lenne Lajos részéről a leghatékonyabb reakció?

a) keményebb munkával behozni az elmaradást (3,2/0)

b) dühöt érezni a munkatárssal szemben $(2,6 / 0)$

c) elmagyarázni a helyzet sürgősségét a munkatársaknak $(5,2 / 1)$

d) soha többé nem bízni ebben a kollegában $(2,4 / 0)$

(Pontozás: a zárójelben bemutatott első érték a szakértők átlagértéke, a második pedig azt jelzi, hogy milyen arányban választották a szakértők a leghatékonyabb válaszalternatívaként az adott választ.) 
A korábbi kutatások a STEU megbízhatóságával kapcsolatban ellentmondásos eredményekhez vezettek (MACCANN és ROBERTS, 2008: a tételek belső konzisztenciáját becslő Cronbach-alfa mutató egyetemista mintán 0,71, nem egyetemista mintán 0,43 volt; AUSTIN, 2010 vizsgálatában hasonló módon alacsony volt a Cronbach-alfa: 0,48). MACCANN és ROBERTS (2008) szerint a STEM megfelelő megbízhatósági mutatóval jellemezhető (a tételek belső konzisztenciáját becslő Cronbach-alfa: 0,68 volt 0-1 pontozás esetén, illetve 0,92, amikor skálák mentén értékelték a résztvevők az egyes válaszalternatívák hatékonyságát). Későbbi kutatások szintén támogatták a STEM reliabilitását (LIBBRECHT és LIEVENS, 2012: Cronbach-alfa: 0,85). A validitást tesztelő kutatások szerint a STEU- és STEMtesztek által mért jellemzők megkülönböztethetőek a személyiségtől (MACCANN és RoberTS, 2008; LibBRECHT és LIEVENS, 2012), közepes korrelációt (STEU $r=$ 0,49; STEM/többszörös választás $r=0,41$; STEM/értékelői skálák nincs kapcsolat) mutatnak a verbális intelligenciát mérő szövegmegértési teszttel (MACCANN és ROBERT, 2008). AUSTIN 2010-ben a STEU és a szövegmegértés között közepes kapcsolatot $(r=0,32)$ talált, de a STEM nem mutatott együttjárást a szövegmegértési teszttel. A korábbi kutatások nem jeleztek összefüggést a STEU/STEM-pontszámok és a fluid intelligencia között (AUSTIN, 2010; LIBBRECHT és LIEVENS, 2012), valamint rámutattak arra, hogy a STEU és a STEM szorosabban kapcsolódik a teljesítményalapú EI-mérésekhez, mint az önbeszámolós EI-mérésekhez. MACCANN és ROBERTS 2008-ban nem talált összefüggést a STEU/STEM-pontszámok és az élettel való elégedettség szintje között, valamint ebben a vizsgálatban az alexithymia skálái közül egyedül a kifelé orientált gondolkodási stílus mutatott közepes erősségű negatív kapcsolatot a STEU $(r=-0,38)$ és a STEM $(r=-0,43)$ pontszámokkal.

Az IQ mérése a kultúrafüggetlen, fluid intelligencia mérésére alkalmas Cattelféle intelligenciateszt alkalmazásával történt (Test of „g” Culture Fair Scale, Form B, Institute for Personality and Ability Testing, Coronado Drive, Champaign, IL, USA). A fluid intelligencia arra a képességre utal, hogy új szituációkban, a már megszerzett tudásunktól függetlenül logikusan gondolkodjunk és megoldjunk problémákat (CATTEL, 1971). Az általános értelmi képességet mérő teszt grafikus alapú, 46 fokozatosan nehezedő ábrákban megfogalmazott feladatból áll. Korábbi hazai vizsgálatok (NAGY, OLÁH és G. TÓTH, 2009; NAGY, 2010) igazolták a skála megbízhatóságát.

A vonás EI-t az AES-HU (NAGY, 2012) alkalmazásával mértük, amely a SALOVEY és MAYER által 1990-ben leírt EI-modellre épül. A vizsgálati személynek egy ötfokozatú skálán kell megítélni, hogy rájuk nézve a felsorolt állítások mennyire igazak (például „Könnyen felismerem az érzelmeimet”). Az eredeti 33 tételből álló kérdőívet SchuTTE és munkatársai 1998-ban dolgozták ki. A skálát a publikálás óta számos tanulmányban használták, ezek többsége támogatta a skála megbízhatóságát és érvényességét (CIARROCHI, CHAN és BAJGAR, 2001; SAKLOFSKE, AUSTIN és Minski, 2003; SchutTe és mtsai, 2001; Kun, BALÁzS, KaPITÁNy, URBÁn és Demetrovics, 2010; Kun és mtsai, 2011), illetve a megfogalmazódó kritikai észrevételek alapján a skála számos módosított verziója is publikálásra került. Jelen 
kutatásban a kérdőív Gignac, Palmer, Manocha és Stough (2005) elemzésére épülő 28 tételes változata került alkalmazásra.

Az érzelmi arcfelismerés képességét mérő Ekman 60 Arc Teszt az EKMAN és FRIESEN által 1978-ban összeállított alapérzelmeket kifejező képgyüjteményre épülő standard módszer. Az Ekman 60 Arc Teszttel kapcsolatos hazai kutatási eredményekről RózsA és munkatársai 2012-ben számoltak be, ezek az eredmények támogatják a skála megbízhatóságát és érvényességét. A számítógépes teszt 60 arcból áll és 10 személyről (6 nő és 4 férfi) készült fényképeket tartalmaz. A 10 modell mindegyike a 6 alapérzelem (düh, undor, félelem, öröm, szomorúság, meglepődés) valamelyikét mutatja, a személynek azt kell eldöntenie, hogy a hat lehetséges érzelem közül melyik írja le legjobban a látott arckifejezést.

A személyiség ötfaktoros elméletére épülő Big Five Inventory (BFI; JOHN, DonAHUE és KenTLE, 1991) 44 tételes kérdőív, az általános személyiségjellemzők öt dimenzióját tárja fel: Extraverzió, Barátságosság, Lelkiismeretesség, Érzelmi instabilitás, Nyitottság. JOHN és SRIVASTAVA 1999-ben végzett vizsgálatának eredményei igazolták a skála megbízhatóságát. Az elmúlt években végzett hazai kutatások szintén a mérőeszköz jó pszichometriai jellemzőit támasztották alá (lásd RózSA és mtsai, 2012).

A Torontó Alexithymia Skála (TAS-20; BAgby, PARker és TAYlor, 1994; BAGBY, TAYLOR és PARKER, 1994) a beszűkült érzelemvilágnak és az érzések kifejezési nehézségének feltárására leggyakrabban használt önjellemző kérdőív, melynek alskálái: 1 . az érzelmek azonosításának nehézsége, 2. az érzelmek kifejezésének nehézsége, 3. kifelé orientált gondolkodási stílus. A TAS-20 megbízhatóságát és érvényességét számos kutatási eredmény igazolja (LINDEN, WENDEN és Paulhus, 1995; Kooiman, Spinhovena, és Trijsburgc, 2002). A magyar egyetemista populáción tesztelt TAS-20 pszichometriai jellemzői az elvárásoknak megfelelöek (CSERJÉSI, LUMINET és LÉNÁRD, 2007; KÖKÖNYEI, 2008).

Az Élettel való Elégedettség Skála (Satisfaction with Life Scale, SWLS; DiENER, EMMONS, LARSEN és GRIFFIN, 1985) a szubjektív jóllét mérésére szolgáló 5 tételből álló, önbeszámolón alapuló kérdőív, amelyben hétfokozatú Likert-skálák alkalmazásával az emberek az életükkel való elégedettségüket olyan tételek mentén értékelik, mint például „Elégedett vagyok az életemmel”. Nemzetközi (DIENER és mtsai, 1985) és hazai vizsgálatok (SzONDY, 2010) egyaránt alátámasztották a skála jó pszichometriai jellemzőit.

\section{EREDMÉNYEK}

\section{Az EI-tesztek leíró jellemzöinek vizsgálata, nemi különbségek az EI területén}

A kutatás során alkalmazott tesztek leíró jellemzőit és megbízhatóságát az 2. táblázatban mutatjuk be. Mintánkban a STEU megbízhatósága alacsonynak (Cronbachalfa: 0,547) bizonyult, és a teszt reliabilitását nem lehetett javítani az alacsonyabb 
2. táblázat. A kutatás során alkalmazott tesztek leíró jellemzői és megbízhatósága

\begin{tabular}{|l|c|c|c|c|}
\hline \multicolumn{1}{|c|}{ S k á l a } & Elemszám & Átlag & Szórás & $\begin{array}{c}\text { Cronbach- } \\
\text { alpha }\end{array}$ \\
\hline AES-HU: Vonás EI összpontszám & 424 & 20,83 & 2,40 & 0,673 \\
\hline Cattel IQ pontszám & 424 & 0,80 & 0,12 & 0,836 \\
\hline $\begin{array}{c}\text { STEU összpontszám: Érzelem- } \\
\text { megértés }\end{array}$ & 424 & 0,53 & 0,10 & 0,549 \\
\hline $\begin{array}{c}\text { STEM összpontszám: Érzelem- } \\
\text { szabályozás }\end{array}$ & 424 & 0,45 & 0,08 & 0,709 \\
\hline SWLS: Élettel való elégedettség & 424 & 4,38 & 1,21 & 0,841 \\
\hline BFI: Extraverzió & 424 & 3,26 & 0,70 & 0,782 \\
\hline BFI: Barátságosság & 424 & 3,62 & 0,59 & 0,742 \\
\hline BFI: Lelkiismeretesség & 424 & 3,47 & 0,62 & 0,786 \\
\hline BFI: Érzelmi stabilitás & 424 & 2,81 & 0,76 & 0,830 \\
\hline BFI: Nyitottság & 424 & 3,62 & 0,58 & 0,774 \\
\hline $\begin{array}{c}\text { TAS: Nehézségek az érzelmek azono- } \\
\text { sításában }\end{array}$ & 424 & 2,26 & 0,71 & 0,803 \\
\hline $\begin{array}{c}\text { TAS: Nehézségek az érzelmek leírá- } \\
\text { sában }\end{array}$ & 424 & 2,54 & 0,83 & 0,776 \\
\hline TAS: Kifelé orientált kognitív stílus & 424 & 2,34 & 0,55 & 0,630 \\
\hline TAS: Alexytímia összpontszám & 424 & 8,13 & 1,20 & 0,718 \\
\hline Ekman 60 Arcok: összpontszám & 424 & 35,99 & 4,03 & 0,652 \\
\hline
\end{tabular}

itemmaradék korrelációjú tételek elhagyásával sem. A STEM megbízhatósága mintánkban éppen meghaladta a 0,7-es határt (Cronbach-alfa: 0,709). A további skálák megbízhatónak bizonyultak, kivéve, hogy valamivel 0,7 alatti megbízhatósági mutatót találtunk a vonás EI-összpontszámot jelző AES-HU (Cronbach-alfa: 0,673), az érzelmi arcfelismerés képességét jelző Ekman 60 Arcok Teszt (Cronbach-alfa: 0,652) és TAS-20 kifelé orientált gondolkodási stílus skála esetén (Cronbach-alfa: 0,630).

A nemi különbségek vizsgálata során (lásd 3. táblázat) szignifikáns eltéréseket találtunk az alábbi mutatók kapcsán a nők javára: vonás $E I$ (nők $\mathrm{M}=21,19, \mathrm{SD}=$ 2,17; férfiak $\mathrm{M}=20,35, \mathrm{SD}=2,46)$ érzelemszabályozás képessége / STEM összpontszám alapján (nők $\mathrm{M}=0,47, \mathrm{SD}=0,06$; férfiak $\mathrm{M}=0,44, \mathrm{SD}=0,09$ ), érzelemfelismerés képessége / Ekman-összpontszám alapján (nők $\mathrm{M}=0,61, \mathrm{SD}=0,05$; férfiak $\mathrm{M}=0,58, \mathrm{SD}=0,08$ ), az ötfaktoros személyiségmodell négy dimenziója (egyedül a Lelkiismeretesség területén nem találtunk nemi eltéréseket): Extraverzió (nők $\mathrm{M}=3,36, \mathrm{SD}=0,66$; férfiak $\mathrm{M}=3,18, \mathrm{SD}=0,70$ ), Barátságosság (nők $\mathrm{M}=3,68$, $\mathrm{SD}=0,58$; férfiak $\mathrm{M}=3,57, \mathrm{SD}=0,62$ ), Érzelmi stabilitás (nők $\mathrm{M}=2,91, \mathrm{SD}=$ 0,74 ; férfiak $\mathrm{M}=2,66, \mathrm{SD}=0,76$ ), Nyitottság (nők $\mathrm{M}=3,69, \mathrm{SD}=0,57$; férfiak $\mathrm{M}=3,56, \mathrm{SD}=0,59)$. A férfiak egyedül az alexithymia egyik faktorán, a nehézségek az érzelmek leírásában értek el magasabb értéket (nők $\mathrm{M}=2,37, \mathrm{SD}=0,79$; férfiak $\mathrm{M}=2,69, \mathrm{SD}=0,83$ ) ami ismételten a nők magasabb érzelmi intelligenciáját támogató eredmény. 
3. táblázat. Nemi különbségek a kutatás során alkalmazott konstruktumok területein

\begin{tabular}{|l|c|c|c|c|c|}
\hline \multicolumn{1}{|c|}{ S k á l a } & $t$ & $\mathrm{df}$ & $\begin{array}{c}\text { Sig. } \\
\text { (2-tailed) }\end{array}$ & Nő/Férfi & Cohen d \\
\hline AES-HU: Vonás EI összpontszám & $-3,774$ & 360 & 0,000 & $\mathrm{~N}$ & $-0,397$ \\
\hline $\begin{array}{c}\text { STEU összpontszám: Érzelem- } \\
\text { megértés }\end{array}$ & $-1,074$ & 360 & 0,284 & - & - \\
\hline $\begin{array}{c}\text { STEM összpontszám: Érzelem- } \\
\text { szabályozás }\end{array}$ & $-4,069$ & 360 & 0,000 & $\mathrm{~N}$ & $-0,425$ \\
\hline SWLS: Élettel való elégedettség & $-1,634$ & 360 & 0,103 & - & - \\
\hline BFI: Extraverzió & $-2,392$ & 360 & 0,017 & $\mathrm{~N}$ & $-0,264$ \\
\hline BFI: Barátságosság & $-1,833$ & 360 & 0,068 & - & - \\
\hline BFI: Lelkiismeretesség & $-1,013$ & 360 & 0,312 & - & - \\
\hline BFI: Érzelmi stabilitás & $-3,148$ & 360 & 0,002 & $\mathrm{~N}$ & $-0,330$ \\
\hline BFI: Nyitottság & $-2,207$ & 360 & 0,028 & $\mathrm{~N}$ & $-0,231$ \\
\hline $\begin{array}{c}\text { TAS: Nehézségek az érzelmek azono- } \\
\text { sításában }\end{array}$ & $-0,573$ & 360 & 0,567 & - & - \\
\hline $\begin{array}{c}\text { TAS: Nehézségek az érzelmek leírá- } \\
\text { sában }\end{array}$ & 3,732 & 360 & 0,000 & $\mathrm{~F}$ & 0,393 \\
\hline TAS: Kifelé orientált kognitív stílus & 3,298 & 360 & 0,001 & $\mathrm{~F}$ & 0,346 \\
\hline TAS: Alexithymia összpontszám & 1,492 & 360 & 0,136 & - & - \\
\hline Ekman 60 Arcok: összpontszám & $-4,384$ & 360 & 0,000 & $\mathrm{~N}$ & $-0,460$ \\
\hline
\end{tabular}

Megjegyzés: 176 férfi és 186 nő adatai alapján

\section{A STEU és STEM validitásához kapcsolódó bizonyitékok}

A szituációs tesztek validitásának elemzése során korrelációkat számoltunk a STEU-, illetve STEM-összpontszám, illetve a vonás EI, az érzelem felismerési képesség, az IQ, az ötfaktoros személyiségmodellben meghatározott személyiség, illetve az alexithymia, valamint az élettel való elégedettség között (lásd 4. táblázat).

A STEU- és STEM-pontszámok között szignifikáns, közepes mértékű, pozitív együtt járást találtunk $(r=0,345 ; p<0,01)$. A korreláció fennmaradt azt követően is, hogy az IQ-ra és a személyiségre kontrolláltuk $(r=0,194, p<0,01)$.

Mind a STEU $(r=0,457, p<0,01)$, mind a STEM $(r=0,383, p<0,01)$ közepes pozitív együttjárást jelzett az intelligencia mértékével.

A vonás EI és a STEU-pontszámok, valamint a vonás EI és a STEM-pontszámok között nem találtunk szignifikáns korrelációt. Az érzelmi arcfelismerés képességét mérő Ekman 60 Arc Teszt pontszáma tendenciaszerű összefüggést mutatott az érzelemszabályozás képességét jelző pontszámmal (STEM $r=0,263$ ), illetve nem állt kapcsolatban az érzelemmegértés képességének szintjével (STEM). 
Az ötfaktoros személyiségmodellben meghatározott faktorok nem jeleztek együttjárást sem a STEU-val, sem a STEM-mel mért EI-vel. Az alexithymia faktorai közül a kifelé orientált gondolkodási stílus pontszáma jelzett tendenciaszerú negatív összefüggést mind az érzelemmegértés képességét mérő (STEU $r=-0,219$ ) mind az érzelemszabályozás képességét mérő pontszámokkal (STEM $r=-0,239$ ).

Az élettel való elégedettség mértéke mintánkban nem mutatott együttjárást sem az érzelemmegértés (STEU), sem az érzelemszabályozás (STEM) pontszámokkal.

4. táblázat. A STEU és a STEM validitásához kapcsolódó bizonyítékok

\begin{tabular}{|c|c|c|c|c|}
\hline & \multicolumn{2}{|c|}{ Pearson-féle korreláció } & \multicolumn{2}{|c|}{$\begin{array}{c}\text { Parciális korreláció } \\
\text { Kontrollált változók: } \\
\text { Cattel IQ pontszám, } \\
\text { BFI vonások }\end{array}$} \\
\hline & STEU & STEM & STEU & STEM \\
\hline $\begin{array}{r}\text { STEU-összpontszám: Érzelem- } \\
\text { megértés }\end{array}$ & 1 & $0,345^{* *}$ & 1 & $0,191^{* *}$ \\
\hline $\begin{array}{r}\begin{array}{r}\text { STEM-összpontszám: Érzelem- } \\
\text { szabályozás }\end{array} \\
\end{array}$ & $0,345^{* *}$ & 1 & $0,191^{* *}$ & 1 \\
\hline AES-HU: Vonás EI összpontszám & 0,094 & $0,109^{*}$ & 0,050 & 0,072 \\
\hline Cattel IQ pontszám & $0,457^{* *}$ & $0,383^{* *}$ & - & - \\
\hline BFI: Extraverzió & 0,048 & $-0,001$ & - & - \\
\hline BFI: Barátságosság & $0,106^{*}$ & $0,160^{* *}$ & - & - \\
\hline BFI: Lelkiismeretesség & 0,035 & 0,011 & - & - \\
\hline BFI: Érzelmi stabilitás & $-0,071$ & 0,005 & - & - \\
\hline BFI: Nyitottság & $0,183^{* *}$ & $0,170^{* *}$ & - & - \\
\hline $\begin{array}{l}\text { TAS: Nehézségek az érzelmek } \\
\text { azonosításában }\end{array}$ & $-0,079$ & $-0,085$ & 0,028 & $-0,053$ \\
\hline $\begin{array}{l}\text { TAS: Nehézségek az érzelmek } \\
\text { leírásában }\end{array}$ & $-0,039$ & $-0,075$ & 0,024 & $-0,047$ \\
\hline $\begin{array}{l}\text { TAS: Kifelé orientált kognitív } \\
\text { stílus }\end{array}$ & $-0,219^{* *}$ & $-0,239^{* *}$ & $-0,092$ & $-0,136^{* *}$ \\
\hline TAS: Alexithymia összpontszám & $-0,043$ & $-0,056$ & 0,015 & 0,014 \\
\hline Ekman 60 Arcok: összpontszám & $0,118^{*}$ & $0,263^{* *}$ & 0,035 & $0,210^{* *}$ \\
\hline SWLS: Élettel való elégedettség & $0,102^{*}$ & $-0,040$ & $-0,002$ & $-0,127^{* *}$ \\
\hline
\end{tabular}

Megjegyzés: "A korreláció szignifikáns, 0,05 százados szinten;

** A korreláció szignifikáns, 0,01 százados szinten. 


\section{DISZKUSSZIÓ}

Jelen kutatás két teljesítményalapú EI-teszt: a STEU és a STEM pszichometriai elemzésére vállalkozott. Az érzelemmegértés képességét mérő STEU az elméletalapú tesztszerkesztés és a sztenderdekre épülő pontozás, az érzelemszabályozás képességét mérő STEM pedig az empirikus tesztszerkesztés és a szakértői pontozás példája az EI-mérés területén. A reliabilitás vizsgálatára irányuló elemzéseink több más kutatás eredményéhez hasonlóan támogatták a STEM megbízhatóságát. A STEU esetében tapasztalt az elvártnál alacsonyabb Cronbach-alfa mutató egybecseng MACCANN és ROBERTS (2008) nem egyetemista mintán történő vizsgálatának eredményével, valamint AUSTIN (2010) vizsgálatának eredményével, amely a jelen kutatáshoz hasonlóan a STEM reliabilitását kielégítőnek, a STEU megbízhatóságát azonban alacsonynak találta. Ez alapján a jövőben - annak érdekében, hogy a sztenderdekre épülő pontozás lehetőségét reálisan értékelhessük az EImérés területén - indokolt a STEU teszt átdolgozása, bővítése további tételek bevonásával. Meg kell jegyeznünk ugyanakkor, hogy az EI teljesítménytesztjei esetében a 0,6-nál valamivel alacsonyabb Cronbach-alfa mutató általánosan előforduló jelenség (lásd NAGY, 2010) és jól magyarázható azzal a ténnyel, hogy ezek a tesztek számos különböző specifikus érzelmet implikálnak, az érzelmi információ feldolgozására vonatkozó kapacitás pedig bizonyítottan különbözhet az egyes érzelmeknél (MACCANn, PeARCE és RoBerTs, 2011). Az érzelmek megértésének képességét mérő STEU 42, az érzelmek szabályozásának képességét mérő STEM 44 hasonló szerkesztésű itemből áll, amelyek csak abból a szempontból különböznek egymástól, hogy milyen érzelmet involválnak az egyes feladatok. A tesztekkel kapcsolatban jogosan felmerülhet az a szakmai kérdés, hogy vajon unidimenzionális szerkezetủ-e a STEU, illetve a STEM, ez az információ kiegészíthetné a megbízhatóságra, item-item korrelációkra vonatkozó elvégzett elemzéseket, valamint a multidimenzionalitás ez esetben az érzelemspecifitás lehetőségét támogatná, vagyis azt, hogy az érzelmi feladatok megoldása során involválódó folyamatok eltérőek lehetnek a különböző érzelmek területén. A MSCEIT, a STEU és a STEM kialakításakor is, annak ellenére, hogy ezek a tesztek sokféle érzelmi problémát involválnak a tesztfejlesztés arra az előfeltevésre épít, hogy nincs szignifikáns intraindividuális variabilitás a specifikus érzelmek feldolgozásában. Későbbi tanulmányok (MaCCANn, PEARCe és Roberts, 2011) e kérdés tisztázása szempontjából megvizsgálták a multidimenzionalitás lehetőségét a STEU és a STEM esetében, ezeknek a kérdéseknek a tisztázásához azonban már nem az eredeti (jelen kutatásban magyarra fordított) itembank szerepelt. Ennek az az oka, hogy az ennek a kérdésnek a korrekt szakmai tesztelésére az eredeti tesztanyag nem tökétesen alkalmas, ugyanis abban nem egyértelmű néhány item esetében, hogy az mely érzelemhez sorolódik, illetve messze nem egyenlő arányban szerepelnek a tételek között a különböző diszkrét emóciókhoz sorolható itemek. MacCann és munkatársai a módosítást annak érdekében hajtottak végre, hogy mindkét teszt minden egyes tétele egyértelműen kapcsolható legyen a félelem, a harag vagy a szomorúság érzéséhez. A módosított feladatsor esetében az érzelemspecifikus faktorok jelenléte (félelem, harag, szomorúság) megerősítést kapott, bár az érzelemspecifikus 
faktorok szorosan korreláltak egymással mindkét esetben. Az érzelemspecifitás problémájának tesztelését a jövőben mi is olyan módosított feladatsorok esetében tervezzük, amelyekben az itemek követhetően és nagyjából egyenlő arányban kapcsolódnak a különböző érzelemkategóriákhoz, illetve újszerủ kezdeményezésként külön szeretnénk tesztelni azt is, hogy külön faktort képeznek-e a pozitív és a negatív érzelem feldolgozásához kapcsolódó tételek, vagy esetleg az unidimenzionális faktorszerkezet a megfelelőbb a STEU és STEM esetében.

A validitást támogató bizonyítékaink vegyesek, és nagyrészt egybecsengnek más kutatások eredményeivel, amelyek a teszt angol nyelvủ verziójára vonatkoznak. A STEU és STEM között megfigyelt közepes mértékủ kapcsolat támogatja azt az elképzelést, mely szerint ezek a tesztek ugyanazt a tágabb konstruktumot mérik. MAYER és munkatársai (2001) szerint az érzelmek észlelését leíró tapasztalati EI elkülönül az érzelmek megértését és szabályozását magában foglaló ún. stratégiai EI-től. Azok a korábbi kutatások, amelyek együttesen alkalmazták a STEU- és STEM-tesztet egybehangzóan közepes mértékű összefüggést figyeltek meg a tesztek által mért pontszámok között (például MACCANN és ROBERTS, 2008; MACCANN és mtsai, 2011). Az az eredményünk, mely szerint a nők érzelemszabályozó képessége (STEM) magasabb a férfiakénál, általánosan megfigyelt jelenség a képességalapú EI mérésének területén (lásd NAGY, 2010), és azok a nemi különbségekre irányuló korábbi kutatások is, amelyek specifikusan a STEM-et alkalmazták az EI mérésére, hasonló eredményre jutottak (MACCANN, 2010; MACCANN és ROBERTS, 2008; AUSTIN, 2010).

Az EI-teszteken elért pontszámok és az intelligenciateszten elért pontszám között tapasztalt közepes erősségű együtt járás szintén az elvárásoknak megfelelő eredmény (lásd korrelációs kritérium, MAYER és mtsai, 1999) és támogatja a szituációs tesztek validitását. Ez az eredmény különösen lényeges a STEM és STEU érvényességével kapcsolatban, mivel az idevonatkozó korábbi kutatások csupán alacsony vagy mérsékelt korrelációkat jeleztek az érzelemszabályozás képessége és a kognitív képességek között, közepes korrelációt a kognitív képességekkel eddig csak az érzelemmegértés vonatkozásában azonosítottak (LIBBRECHT és LiEvENS, 2012; MACCANn és RoberTs, 2008; Austin, 2010). A korábbi kutatások eredményei felvetették annak lehetőségét, hogy csak az érzelmek megértése tekinthető esélyes „intelligenciajelöltnek”, mivel a STEM által mért jellemző függetlennek bizonyult az intelligenciától, a MSCEIT faktorai közül pedig csak az érzelemmegértés korrelált közepes mértékben az IQ-val, ezért figyelemre méltó lehet az az eredményünk, amely rámutat az érzelemszabályozás és a fluid intelligencia közepes mértékű együttjárására.

A validitást támogatja az az eredményünk is, mely szerint a szituációs tesztek mintánkban nem mutattak összefüggést a vonás EI-vel. A vonás EI-vel való kapcsolat tesztelése a STEM és STEU divergens validitásának igazolása miatt fontos. Ezzel az eredménnyel egybecsengően számos korábbi kutatás (BASTIAN, BURNS és NetTelbeck, 2005; Brackett és Mayer, 2003; O'Connor és LitTle, 2003) támogatta azt az elképzelést mely szerint a vonás EI és a képesség EI két megkülönböztethető konstruktum (PETRIDES és FURNHAM, 2001). Teljesült az az elvárásunk is, amely értelmében az EI-teszteken elért pontszám legfeljebb alacsony mértékű 
korrelációt mutathat a személyiséggel (lásd korrelációs kritérium, MAYER és mtsai, 1999). Mintánkban a teljesítményalapú EI-tesztek függetlennek bizonyultak az ötfaktoros személyiségmodellben meghatározott faktoroktól.

Ugyanakkor a validitás szempontjából néhány eredményünk nem az elvárásoknak megfelelő és kérdéseket vet fel. Idesorolható az a STEU-ra vonatkozó eredményünk, mely szerint a teszt szorosabb kapcsolatot jelzett az intelligenciával, mint a STEM-mel, illetve hasonló problémát vet fel, hogy eredményeink szerint a STEM ugyanolyan mértékben korrelált a STEU-val, mint az IQ-val. Hasonló problémára mutatott rá MACCANN és ROBERT (2008) is, amikor vizsgálatukban a MSCEIT egyik altesztjén elért érték (Történetek alteszt) és a STEU-pontszám között jelentkező korreláció alacsonyabbnak bizonyult, mint a STEU- és IQ-pontszámok között megfigyelt kapcsolat. Az érzelemfelismerő képességet mérő tesztek alkalmazása kulcs kritériumváltozó, ha az EI-tesztek validitását akarjuk tesztelni, mivel az érzelempercepció a legalapvetőbb érzelmi képesség, amire minden más érzelmi képesség épül, ráadásul ezek a tesztek nem tartalmaznak szituációs jelzéseket, a velük való kapcsolat ezért különösen lényeges lehet a validitás igazolása során. Mintánkban az érzelemfelismerést mérő tesztben nyújtott teljesítmény azonban nem jelzett együttjárást a STEU-val és STEM-mel mért teljesítményekkel, illetve korábbi kutatások (ROBERTs és mtsai, 2006) szintén csak alacsony kapcsolatot találtak a stratégiai EI és az érzelemfelismerő feladatokban nyújtott teljesítmények között. Ez a szituációs tesztekkel kapcsolatban a konvergens validitásnak egy olyan hiánya, amit a későbbi kutatásokban tisztázni kell. A korábbi kutatások eredményei alapján azt vártuk, hogy a STEU- és STEM-pontszámok kismértékben negatívan korrelálnak majd az alexithymia pontszámmal (BARCHARD és HAKSTIAN, 2004; WARWick és NETTELBECK, 2004), illetve kismértékű pozitív kapcsolatot mutatnak az élettel való elégedettséggel (BASTIAN és mtsai, 2005; Ciarrochi, Chan és CAPUTI, 2000; MaYer és mtsai, 1999). Mintánkban az alexithymia faktorai közül csupán a kifelé orientált gondolkodási stílus pontszám jelzett tendenciaszerű negatív együttjárást mind az érzelemmegértés, mind az érzelemszabályozás képességét mérő értékekkel. A validitással kapcsolatban problémát jelent, hogy a STEU- és STEM-pontszámok nem függtek össze az alexithymia másik két aspektusával (nehézségek az érzelmek azonosításában; nehézségek az érzelmek leírásában), valamint hogy az élettel való elégedettség vonatkozásában sem kaptunk az elvárásoknak megfelelő eredményt.

Konklúzióként megállapíthatjuk, hogy további vizsgálatok szükségesek, ha igazolni szeretnénk, hogy a STEU- és STEM-tesztek inkább mérnek érzelmi intelligenciát, mint más kognitív képességet, illetve hogy az EI-feladatok együttesen egy különálló faktort alkotnak, amely megkülönböztethető más kognitív képességektől.

\section{LIMITÁCIÓK, JÖVŐBELI KUTATÁSI LEHETŐSÉGEK}

Jelen kutatás erőssége, hogy az EI mérésére 3 megkülönböztethető mérési paradigmát is alkalmazott: 1. szituációkat értékelő tesztekkel mértük a stratégiai EI-t, 
2. érzelemfelismerő képességet mérő feladattal mértük a tapasztalati EI-t, 3. önjellemző kérdőívek alkalmazásával mértük az észlelt érzelmi én-hatékonyság szintjére utaló vonás EI-t. Kutatásunk értékelésével kapcsolatban azonban meg kell jegyeznünk, hogy jelentős korlátot jelent a pszichológushallgatókból álló minta alkalmazása, ez a minta ugyanis atipikus az érzelmekkel kapcsolatos tudás, valamint a szociális és érzelmi jelenségek iránti érdeklődés szempontjából. A jövőben nem pszichológushallgatókból álló minta bevonásával kívánjuk folytatni a szituációs tesztek jellemzőinek elemzését, fontosnak tartjuk tesztelni, hogy mennyiben befolyásolják a szituációkkal kapcsolatos személyes tapasztalatok a megoldásokat, illetve tervezzük az itemek video- vagy audioalapú prezentációját is a célból, hogy teszteljük a szövegmegértés hatását az eredményekre. A STEM és az intelligencia között megfigyelt együttjárás további megerősítése indokolt lehet további fluid intelligenciát mérő tesztek alkalmazásával, valamint az inkrementális validitás tesztelése céljából a jövőben fontos lesz a szituációs tesztek és a testi-lelki egészségi állapot együtt járásainak elemzése is.

\section{IRODALOM}

Austin, E. J. (2010). Measurement of ability EI: Results for two new tests. British Journal of Psychology, 101(3), 563-578.

Bagby, R. M., Parker, J. D. A., \& Taylor, G. J. (1994). The twenty-item Toronto Alexithymia Scale I. Item selection, and cross-validation of the factor structure. Journal of Psychosomatic Research, 38, 23-32.

Bagby, R. M., Taylor, G. J., \& Parker, J. D. A. (1994). The twenty-item Toronto Alexithymia Scale II. Convergent, discriminant, and concurrent validity. Journal of Psychosomatic Research, 38, 33-40.

Barchard, K. A., \& Hakstian, R. A. (2004). The nature and measurement of emotional intelligence abilities: Basic dimensions and their relationships with other cognitive ability and personality variables. Educational and Psychological Measurement, 64, 437-462.

Bastian, V. A., Burns, N. R., \& Nettelbeck, T. (2005). Emotional intelligence predicts life skills, but not as well as personality and cognitive abilities. Personality and Individual Differences, 39, 1135-1145.

Beaton, D. E., Bombardier, C., Guillemin, F., \& Ferraz, M. B. (2000). Guidelines for the process of cross-cultural adaptation of self-report measures. Spine, 25(31), 86-91.

Brackett, M., \& MAYER, J. D. (2003). Convergent, discriminant, and incremental validity of competing measures of emotional intelligence. Personality and Social Psychology Bulletin, 29, 1147-1158.

CATtel, R. B. (1971). Abilities: Their structure, growth, and measurement. Boston: Houghton Mifflin.

Ciarrochi, J. V., Chan, A. Y. C., \& Caputi, P. (2000). A critical evaluation of the emotional intelligence construct. Personality and Individual Differences, 28, 539-561.

Ciarrochi, J. V., Chan, A. Y. C., \& BajGar, J. (2001). Measuring emotional intelligence in adolescents. Personality and Individual Differences, 31, 1105-1119. 
Cserjési R., Luminet O. és LÉNÁRD L. (2007). A Torontói Alexitímia Skála (TAS-20) magyar változata: megbízhatósága és faktorvalidítása egyetemista mintán. Magyar Pszichológiai Szemle, 62(3), 301-314.

Diener, E., Emmons, R. A., Larsen, R. J., \& Griffin, S. (1985). The Satisfaction with Life Scale. Journal of Personality Assessment, 49, 71-75.

Ekman, P., \& Friesen, W. V. (1978). Facial action coding system: Investigator's guide. Palo Alto, Calif: Consulting Psychologist Press.

Gignac, C. E., Palmer, B. R., Manocha, R., \& Stough, C. (2005). An examination of the factor structure of the Schutte self-report emotional intelligence (SSREI) scale via confirmatory factor analysis. Personality and Individual Differences, 39, 1029-1042.

John, O. P., Donahue, E. M., \& Kentle, R. (1991). The „Big Five” inventory - Versions $4 a$ and 54. Berkeley: University of California, Berkeley, Institute of Personality and Social Research.

John, O. P., \& SRivastava, S. (1999). The Big-Five Trait Taxonomy: History, Measurement, and Theoretical Perspectives. In L. A Pervin \& O. P. John (Eds.), Handbook of personality: Theory and Research (102-138). New York: Guilford Press.

KeEle, S. M., \& Bell, R. C. (2008). The factorial validity of emotional intelligence: An unresolved issue. Personality and Individual Differences, 44, 487-500.

Koomman, C. G., Spinhovena, P., \& TrijsburgC, R. W. (2002). The assessment of alexithymia A critical review of the literature and a psychometric study of the Toronto Alexithymia Scale-20. Journal of Psychosomatic Research, 53, 1083-1090.

KÖKÖNyEI GY. (2008). Érzelemszabályozás krónikus fájdalomban. Doktori disszertáció, Budapest: ELTE PPK.

Kun, D., Balázs, H., Kapitány, M., Urbán, R., \& Demetrovics, Zs. (2010). Confirmation of the three factor model of the Assessing Emotions Scale (AES): Verification of the theoretical starting point. Behavioral Research Methods 42(2), 596-606.

Kun, D., Urbán, R., Balázs, H., Kapitány, M., Nagy, H., OláH, A., \& Demetrovics, Zs. (2011). Az érzelmek mérése skála háromfaktoros modelljének adaptálása. Magyar Pszichológiai Szemle 66(3), 449-466.

LEGREE, P. J. (1995). Evidence for an oblique social intelligence factor established with a Likert-based testing procedure. Intelligence, 21, 247-266.

Libbrecht, N., \& Lievens, F. (2012). Validity evidence for the situational judgment test paradigm in emotional intelligence measurement. International Journal of Psychology, 47(6), 438-447.

Linden, W., Wenden, F., \& Paulhus, D. L. (1995). Measuring alexithymia: reliability, validity, and prevalence. In J. Butcher, \& C. SPIELberger (Eds.), Advances in Personality Assessment (51-95). Hillsdale, NJ: Lawrence Erlbaum Associates.

MaCCANn, C. (2010). Further examination of emotional intelligence as a standard intelligence: A latent variable analysis of fluid intelligence, crystallized intelligence, and emotional intelligence. Personality and Individual Differences, 49, 490-496.

MacCann, C., \& Roberts, R. D. (2008). New paradigms for assessing emotional intelligence: Theory and data. Emotion, 8(4), 540-551.

MacCann, C., Pearce, N., \& Roberts, R. D. (2011). Emotional Intelligence as assessed by Situational Judgment and Emotion Recognition Tests: Building the nomological Net. Psychological Topics 20(3), 393-412. 
Matthews, G., Zeidner, M., \& Roberts, R. D. (2007). Emotional intelligence. Consensus, controversies, and questions. In G. Matthews, M. Zeidner, \& R. D. Roberts (Eds.), The science of emotional intelligence. Knowns and unknowns (3-46). New York: Oxford University Press.

Mayer, J. D., \& Salovey, P. (1997). What is emotional intelligence? In P. SAlovey, D. SLUYTER (Eds.), Emotional development and emotional intelligence (3-31). New York: Basic Books.

Mayer, J. D., Salovey, P., \& Caruso, D. (1997). Emotional IQ test [CD ROM]. Needhamn, MA: Virtual Knowledge.

Mayer, J. D., Caruso, D. R., \& Salovey, P. (1999). Emotional intelligence meets traditional standards for an intelligence. Intelligence, 27, 267-298.

Mayer, J., Salovey, P., Caruso, D. R., \& Sitarenios, G. (2001). Emotional intelligence as a standard intelligence (peer commentaries). Emotion 1(3), 232-242.

Mayer, J., Salovey, P., \& Caruso, D. (2002). The Mayer, Salovey, and Caruso Emotional Intelligence Test: Technical manual. Toronto, Canada: Multi-Health Systems.

Mayer, J. D., Roberts, R. D., \& Barsade, S. G. (2008). Human abilities: Emotional intelligence. Annual Review of Psychology, 59, 507-536.

McDaniel, M. A., Morgeson, F. P., Finnegan, E. B., Campion, M. A., \& Braverman, E. P. (2001). Use of situational judgement tests to predict job performance: A clarification of the literature. Journal of Applied Psychology, 86, 730-740.

NaGy H., OlÁH A. és G. TóTH K. (2009). Az érzelmi intelligencia mérésének néhány problémája: a fejlődési kritérium tesztelése. Pszichológia 29(2), 165-186.

NAGY H. (2010). A képességalapú érzelmi intelligencia modell érvényességének empirikus elemzése. Phd. disszertáció. Eötvös Loránd Tudományegyetem, Pedagógiai és Pszichológiai Kar, Pszichológiatudomány Doktori Iskola.

NAGY H. (2012). Az Érzelmek Mérése Skála (AES-HU) faktorszerkezetének és validitásának elemzése, Magyar Pszichológiai Szemle, 67(3), 431-447.

O'Connor, R. M., \& LitTle, I. S. (2003). Revisiting the predictive validity of emotional intelligence: Self-report versus ability-based measures. Personality and Individual Differences, 35, 1893-1902.

Palmer, B. R., Gignac, G., Manocha, R., \& Stough, C. (2005). A psychometric evaluation of the Mayer-Salovey-Caruso emotional intelligence test version 2.0. Intelligence, 33, 285-4305.

Petrides, K. V., \& Furnham, A. (2001). Trait emotional intelligence: Psychometric investigation with reference to established trait taxonomies. European Journal of Personality 15, $425-448$.

Roberts, R. D., Zeidner, M., \& Matthews, G. (2001). Does emotional intelligence meet traditional standards for an intelligence? Some new data and conclusions. Emotion, 1, 196-231.

Roberts, R. D., Schulze, R., O’Brien, K., MacCann, C., Reid, J., \& Maul, A. (2006). Exploring the validity of the Mayer-Salovey-Caruso Emotional Intelligence Test (MSEIT) with established emotions measures. Emotion, 6, 663-669.

Roseman, I. J. (2001). A model of appraisal in the emotions system: Integrating theory, research, and applications. In K. R. SCHERER, \& A. SCHORR (Eds.), Appraisal processes in emotion: Theory, methods, research (68-91). New York: Oxford University Press. 
Rossen, E., Kranzler, J. H., \& Algina, J. (2008). Confirmatory factor analysis of the Mayer-Salovey-Caruso Emotional Intelligence Test V 2.0 (MSCEIT). Personality and Individual Differences, 44, 1258-1269.

RózSA S., Kálmán R., Kỏ N., Nagy H., Fiáth T. és OláH A. (2012). Az érzelmi arcfelismerés mérése és jelentôsége a pszichológiai kutatásokban: Az Ekman 60 Arc Teszttel szerzett hazai tapasztalatok, Pszichológia, 32(3), 229-251.

SAklofske, D. H., Austin, E. J., \& Minski, P. (2003). Factor structure and validity of a trait emotional intelligence measure. Personality and Individual Differences, 34, 707-721.

SAlovey, P., \& MAYer, J. D. (1990). Emotional Intelligence. Imagination Cognition, and Personality, 9, 185-211.

Schutte, N. S., Malouff, J. M., Hall, L. E., Haggerty, D. J., Cooper, J. T., Golden, C. J., \& Dornheim, L. (1998). Development and validation of a measure of emotional intelligence. Personality and Individual Differences, 25(2), 167-177.

Schutte, N. S., Malouff, J. M., Bobnik, C., Coston, T. D., Greeson, C., Jedlicka, C., RHOdes, E., \& WENDORF, G. (2001). Emotional intelligence and interpersonal relations. Journal of Social Psychology, 141, 523-536.

Szondy M. (2010). Optimizmus, pesszimizmus, egészség. Doktori disszertáció, ELTE, Budapest. Warwick, J., \& Nettelbeck, T. (2004). Emotional intelligence is? Personality and Individual Differences, 37, 1091-1100.

Zeidner, M., Matthews, G., \& Roberts, R. D. (2001). Slow down, you move too fast: Emotional intelligence remains an 'elusive' intelligence. Emotion, 1(3), 265-275.

\title{
MEASUREMENT OF ABILITY EMOTIONAL INTELLIGENCE: SITUATIONAL TEST OF EMOTIONAL UNDERSTANDING AND SITUATIONAL TEST OF EMOTION MANAGEMENT
}

\author{
NAGY, HENRIETT - MAGYARÓDI, TÍMEA - SÉLLEI, BEATRIX
}

This article focuses on two alternative tests to assess emotional intelligence (EI): Situational Test of Emotional Understanding (STEU) and the Situational Test of Emotion Management (STEM). These questionnaires follow two new approaches of EI assessment because the STEU test is based on standard-based scoring approach and the STEM test is applied by the situational judgement test method in test development. The purposes of the current study were to establish the Hungarian versions of the STEU and the STEM and to provide some further reliability and validity evidences for these two questionnaires. To demonstrate the validity of these situational tests we examined the relationships between the STEU and the STEM scores with fluid intelligence, trait-EI, emotion recognition ability, personality, alexythimia and life satisfaction. As a conclusion the used new paradigms concerning to test development and scoring are useful and promising in the area of the measurement of ability-based EI, however further studies are needed to confirm that these tests assess emotional intelligence not some other cognitive group factors.

Key words: ability-based EI, Situational Test of Emotional Understanding, Situational Test of Emotion Management 